\title{
Climatic change in mountain regions: a review of possible impacts
}

\author{
Martin Beniston \\ Department of Geosciences \\ University of Fribourg \\ Switzerland
}

\begin{abstract}
This paper addresses a number of issues related to current and future climatic change and its impacts on mountain environments and economies, focusing on the "Mountain Regions" Chapter 13 of Agenda 21, a basis document presented at the 1992 United Nations Conference on Environment and Development (UNCED) in Rio de Janeiro, and the International Year of the Mountains (IYM) 2002. The awareness that mountain regions are an important component of the earth's ecosystems, in terms of the resources and services that they provide to both mountain communities and lowland residents, has risen in the intervening decade. Based upon the themes outlined in the supporting documents for IYM, this paper will provide a succinct review of a number of sectors that warrant particular attention, according to IYM. These sectors include water resources, ecosystems and biological diversity, natural hazards, health issues, and tourism. A portfolio of research and policy options are discussed in the concluding section, as a summary of what the IYM and other concerned international networks consider to be the priority for mountain environmental protection, capacity building, and response strategies in the face of climatic change in the short to medium term future.
\end{abstract}

\section{Introduction}

In June 1992, the United Nations Conference on Environment and Development (UNCED, Rio de Janeiro) addressed a range of issues pertaining to sustainable development as a means of reducing human-induced environmental stress, in a document referred to as Agenda 21. Chapter 13 of this program is exclusively devoted to mountain regions and, for the first time, an official and explicit recognition that mountains and uplands are a major component of the global environment has emerged. Chapter 13 sets the scene by stating the role of mountains within the global ecosystem, and expresses serious concerns related to the decline in the general environmental quality of many mountains. A summarized version (UN, 1992) of Agenda 21/13 reads:

"Mountains are important sources of water, energy, minerals, forest and agricultural products and areas of recreation. They are storehouses of biological diversity, home to endangered species and an essential part of the global ecosystem. From the Andes to the Himalayas, and from Southeast Asia to East and Central Africa, there is serious ecological deterioration. Most mountain areas are experiencing environmental degradation.”

Significant orographic features occupy close to 25\% of continental surfaces (Kapos et al., 2000) and, although only about $26 \%$ of the world's population resides within mountains or in the foothills of the mountains (Meybeck et al., 2001), mountain-based resources indirectly provide sustenance for over half. Moreover, $40 \%$ of global population lives in the watersheds of rivers originating in the planet's different mountain ranges.

Mountains also represent unique areas for the detection of climatic change and the assessment of climate-related impacts. One reason for this is that, as climate changes rapidly with height over 
relatively short horizontal distances, so does vegetation and hydrology (Whiteman, 2000). As a consequence, mountains exhibit high biodiversity, often with sharp transitions (ecotones) in vegetation sequences, and equally rapid changes from vegetation and soil to snow and ice. In addition, mountains ecosystems are often endemic, because many species remain isolated at high elevations compared to lowland vegetation communities that can occupy climatic niches spread over wider latitudinal belts. Certain mountain chains have been referred to as "islands" rising above the surrounding plains (Hedberg, 1964), such as those in East Africa. In socio-economic terms, mountain landscapes attract large numbers of people in search of opportunities for recreation and tourism. However, the environmental stress imposed by growing numbers of tourists is placing an increasingly heavy burden on mountain resources (Godde et al., 2000) and, in many parts of the developing world in particular, on local communities.

With the rapid industrialization and population growth that the $20^{\text {th }}$ century has witnessed worldwide, the natural environment has undergone unprecedented changes. While the causal mechanisms of environmental and climatic change are numerous and complex, two factors can be highlighted to explain the increasing stress imposed by human interference on the natural environment: economic growth and population growth. The economic level of a country determines to a large extent its resource requirements, in particular energy, industrial commodities, agricultural products and fresh water supply. Rising population levels, on the other hand, can weigh heavily upon the resources available per capita, particularly in less affluent countries.

Bearing these two factors in mind, environmental deterioration in mountains can be driven by numerous factors that include deforestation, over-grazing by livestock and cultivation of marginal soils. Mountain ecosystems are susceptible to soil erosion, landslides and the rapid loss of habitat and genetic diversity. In many developing countries, in part because of the degradation of the natural environment, there is widespread unemployment, poverty, poor health and bad sanitation (Price et al., 2000). Such concerns have prompted a number of research and policy initiatives that have acknowledged and highlighted the importance of mountain environments in environmental, economic, and social terms. Perhaps the most notable action, at least in terms of policy, has been the proclamation, by the UN General Assembly in 1998 (UN, 1998), of the year 2002 as the "International Year of the Mountains" (IYM), declaring that:

"The aim of IYM is to ensure the well-being of mountain and lowland communities by promoting the conservation and sustainable development of mountain regions. FAO [the United Nations Food and Agricultural Organization], the lead agency for IYM, is working closely with UN and other organizations to make sure the broadest possible range of expertise is focused on reaching the goals of sustainable mountain development. One of IYM's goals is to raise awareness about the challenges in protecting mountain habitats and improving living standards in mountain communities."

The IYM is aimed at furthering ongoing actions and stimulating new initiatives related to the following sectors:

- Natural resources, particularly climate, water, soils, biodiversity, and forests;

- Resource use, namely water, agriculture, forestry, and mining;

- Socio-economic issues, such as tourism, trade and transportation, people and culture, and financial mechanisms and strategies; 
- Integrated themes, with a focus on health and well-being, risks and hazards, watershed management, mountain protected areas, integrated mountain development, conflicts, and policies.

In the general framework of IYM-2002, mountains indeed offer interesting research opportunities. In the remote mountain environments of high altitudes or latitudes, there is the potential for investigating the impacts of environmental change in the absence of direct or significant human interference. Furthermore, because of the latitudinal range and varying degree of continentality of mountains distributed around the globe, comparative analyses can be undertaken to assess the manner in which climatic change may lead to similarities - or differences - in the response of environmental and socio-economic systems to change.

This paper will provide a brief review of climatic change, as it may influence different mountain regions of the world, with a focus on a number of impacts sectors considered to be important in the IYM framework, namely:

- Water, snow and ice: because the hydrological cycle will be enhanced under warmer climatic conditions, the current distribution, seasonality, and amount of precipitation may undergo significant changes in various geographical regions. The consequences for river runoff are likely to affect not only the watersheds within the mountains themselves, but also in the lowland regions that are heavily dependent on this mountain resource;

- Vegetation, forests, and biodiversity: biodiversity in mountain areas encompasses both natural and cultivated species; these systems are all sensitive to climatic factors and are likely to have different vulnerability thresholds according to the species, the amplitude, and the rate of climatic change. The preservation and enhancement of vegetation cover in natural, seminatural, agricultural, forest, and agroforestry ecosystems is an essential factor in sustaining environmental health in mountains, in helping to avert natural hazards such as landslides through the upkeep of adequate vegetation cover, and in maintaining water quality;

- Health: changing climates may lead to new distributions of vector-borne disease. A particularly interesting example in the context of mountains and uplands is the possible propagation of malaria as an indicator of climatic change. Regions that are today unfavorable for the development of the disease, which is in part climatically-driven, may open up to malaria in areas that would experience more favorable temperature and moisture conditions than today;

- Tourism: over the last 25 years, tourism and recreation has been one of the fastest growing industries worldwide. Tourism has both economic benefits for, and potential adverse effects on, mountain environments and local mountain communities. Changing climates may alter the seasonal patterns of tourism (for example, skiing in winter), and thus the environmental pressures associated with different forms of tourism.

The conclusions section will focus on possible policy options, based for example on the protection of natural resources in mountain regions, and recommendations for research agendas in mountains and uplands.

\section{Possible consequences of climatic change in mountain regions}

Although mountains differ considerably from one region to another, one common feature is the complexity of their topography. Orographic features include some of the sharpest gradients found in continental areas. Related characteristics include rapid and systematic changes in climatic 
parameters, in particular temperature and precipitation, over very short distances (Becker and Bugmann, 1997); greatly enhanced direct runoff and erosion; systematic variation of other climatic (e.g., $\mathrm{CO}_{2}$, radiation) and environmental factors, such as differences in soil types. In some mountain regions, it has been shown that there is an elevation dependency on temperature trends and anomalies (e.g., Beniston and Rebetez, 1996 for the Alps; Giorgi et al., 1997), a feature that is not, however, systematically observed in other upland areas (e.g., Vuille and Bradley, 2000, for the Andes). Mountains in many parts of the world are susceptible to the impacts of a rapidly changing climate, and provide interesting locations for the early detection and study of the signals of climatic change and its impacts on hydrological, ecological, and societal systems.

The complexity and mutual inter-dependency of mountain environmental and socio-economic systems pose significant problems for climate impacts studies (Beniston et al., 1997). For assessing current and future trends in regional climate, the current spatial resolution of General Circulation Models (GCM) is generally too crude to adequately represent the orographic detail of most mountain regions. On the other hand, most impacts research requires information with fine spatial definition, where the regional detail of topography or land-cover are important determinants in the response of natural and managed systems to change. Since the mid-1990s, the scaling problem related to complex orography has been addressed through regional modeling techniques, pioneered by Giorgi and Mearns (1991), and through statistical-dynamical downscaling techniques (e.g., Zorita and von Storch, 1999).

So-called "nested" approaches to regional climate simulations, whereby large-scale data or GCM outputs are used as boundary and initial conditions for regional climate model (RCM) simulations, have been applied to scenario computations for climatic change in the $21^{\text {st }}$ century (Giorgi and Mearns, 1999). The technique is applied to specific periods in time ("time slices" or "time windows") for which high-resolution simulations are undertaken. GCM results for a given time window include the long-term evolution of climate prior to that particular time frame, based on an incremental increase of greenhouse gases over time. The RCM focuses on a high-resolution simulation for the limited time span of the selected time window over a given geographical area. The nested modeling approach represents a trade-off between decadal- or century-scale, high resolution simulations that are today unattainable, even with currently-available computational resources, and relying only on coarse resolution results provided by long-term GCM integrations. Although the method has a number of drawbacks, in particular the fact that the nesting is "oneway" (i.e., the climatic forcing occurs only from the larger to the finer scales and not vice-versa), RCMs may in some instances improve regional detail of climate processes. This can be an advantage in areas of complex topography, where for example orographically-enhanced precipitation may represent a significant fraction of annual or seasonal rainfall in a particular mountain region. Such improvements are related to the fact that RCM simulations capture the regional detail of forcing elements like orography or large lakes, and the local forcings of such features on regional climate processes, in a more realistic manner than GCMs (Beniston, 2000).

Over time, the increase in spatial resolution of RCMs has allowed an improvement in the understanding of regional climate processes and the assessment of the future evolution of regional weather patterns influenced by a changing global climate. Marinucci et al. (1995) tested the nested GCM-RCM technique at a 20-km resolution to assess its adequacy in reproducing the salient features of contemporary climate in the European Alps, while Rotach et al. (1997) repeated the numerical experiments for a scenario of enhanced greenhouse-gas forcing. Over the past 5 years, RCM spatial resolution has continually increased, partially as a response to the needs of the impacts community. Currently, detailed simulations with $5 \mathrm{~km}$ or even $1 \mathrm{~km}$ grids are used to investigate the details of precipitation in relation to surface runoff, infiltration, and evaporation 
(e.g., Arnell, 1999; Bergström et al. 2001), extreme events such as precipitation (Frei et al., 1998), and damaging wind storms (Goyette et al., 2001).

\subsection{The hydrological cycle and water resource use}

A warming climate as projected by General Circulation Models (IPCC, 1996; 2001) will enhance the hydrological cycle. This implies higher rates of evaporation, and a greater proportion of liquid to solid precipitation; these physical mechanisms, associated with potential changes in precipitation amount and seasonality, will affect soil moisture, groundwater reserves, and the frequency of flood or drought episodes. Although water is present in ample quantity at the Earth's surface, the supply of water is limited and governed by the renewal processes associated with the global hydrological cycle. With the expansion of human settlements and the growth of industrial activities, water has been increasingly used for the assimilation and discharge of wastes. This resource has been taken for granted, and only in the past few decades has increasing water shortage and declining water quality from pollution drawn attention to the inherent fragility and scarcity of water. This has led to concerns about water availability to meet the requirements of the $21^{\text {st }}$ century (Shiklomanov, 2001).

Projections of changes in precipitation patterns in mountains are tenuous in most General Circulation Models because mountain topography is poorly resolved and, as a result, the controls of topography on precipitation are not adequately represented. In addition, it has been recognized more recently that the superimposed effects of natural modes of climatic variability such as El Nino/Southern Oscillation (ENSO) or the North Atlantic Oscillation (NAO) can perturb mean precipitation patterns on time scales ranging from seasons to decades. These are important mechanisms to take into account but are still not well predicted by climate models. Recent coupled ocean-atmosphere GCM simulations are more encouraging, however (Osborn et al., 1999).

Snow and ice are, for many mountain ranges, a key component of the hydrological cycle, and the seasonal character and amount of runoff is closely linked to cryospheric processes. In addition, because of the sensitivity of mountain glaciers to temperature and precipitation, the behavior of glaciers provides some of the clearest evidence of atmospheric warming and changes in the precipitation regime, both modulated by atmospheric circulation and flow patterns over the past decades (Haeberli and Beniston, 1998; WGMS, 2000). Changes in climate has been shown to result in shifts in seasonal snow pack (Dettinger et al., 2002); glacier melt influences discharge rates and timing in the rivers that originate in mountains. In temperate mountain regions, the snow-pack is often close to its melting point, so that it may respond rapidly to apparently minor changes in temperature. As warming progresses in the future, regions where snowfall is the current norm will increasingly experience precipitation in the form of rain. For every ${ }^{\circ} \mathrm{C}$ increase in temperature, the snowline will rise by about $150 \mathrm{~m}$. Shifts in snow-pack duration and amount as a consequence of sustained changes in climate will be crucial factors in water availability for hydrological basins.

Some attempts at modeling the snow-pack have been undertaken to determine how this may change in a warmer global climate. Martin and Durand (1998) have used a snow model to investigate the manner in which snow amount and duration is likely to shift in the French Alps under changing climatic conditions. Using the SAFRAN-CROCUS snow model, incorporated into the French ARPEGE GCM, an assessment of the most sensitive areas of the French Alps has been undertaken. Sensitivity studies show that below elevations of about 1,500 $\mathrm{m}$, snow amount and duration may be sharply reduced compared to today, especially in the southern part of the 
French Alps. Reduced snow cover will have a number of implications, in particular for early seasonal runoff (Dettinger et al., 2002), and the triggering of the annual cycle of mountain vegetation (Cayan et al., 2001).

Decadal-scale variability of Alpine climate also needs to be considered in the context of climateimpacts assessments, and for much of western Europe and the eastern third of North America, the North Atlantic Oscillation (NAO) exerts significant controls on climate (Hurrell and van Loon, 1997). Beniston (1997), for example, has shown that snow cover and duration in the Swiss Alps is particularly well correlated with the NAO index, which is a measure of the intensity of westerly flow and associated storm tracks across the North Atlantic. In terms of the indirect effects on hydrology, Beniston and Jungo (2001) have shown that when the NAO index is high, the distribution of winter temperatures at high elevations in the Alps (exceeding 1,000m above sea level) shifts towards higher values, compared to when the NAO index is low. The frequency of temperatures exceeding the freezing point during the winter season is more than doubled, as illustrated in Figure 1, thus enhancing the potential for early snowmelt.

\section{Insert Figure 1 here}

Glaciers exist on all continents except Australia and at virtually all latitudes from the tropics to the poles, and mountain glaciers are valuable indicators of climate change. The volume of ice in a glacier, and correspondingly its surface area, thickness, and length, is determined by the balance between inputs (accumulation of snow and ice) and outputs (melting and calving); these are largely controlled by temperature, humidity, wind speed, and other factors like slope angle and ice albedo (Fitzharris et al., 1996). As climate changes, this balance may be altered, resulting in a change in thickness and the advance or retreat of the glacier. Since 1850 the glaciers of the European Alps have lost about 30 to $40 \%$ of their surface area and about half of their volume (Haeberli and Beniston, 1998). Similarly, glaciers in the Southern Alps of New Zealand have lost $25 \%$ of their area over the last 100 years (Chinn, 1996), and glaciers in several regions of central Asia have been retreating since the 1950s (Fitzharris, 1996; Meier, 1998). The seven-year average rate of ice loss for several glaciers monitored in the US Pacific Northwest was higher for the period since 1989 than for any other period studied (Hodge et al., 1998). Glacial retreat is also prevalent in the higher elevations of the tropics, and Mt. Kenya and Kilimanjaro have lost over $60 \%$ of their ice cover in the last century (Hastenrath and Greischar, 1997); accelerated retreat has also been reported for the tropical Andes (Thompson et al., 2000).

Empirical and energy-balance models indicate that $30-50 \%$ of existing mountain glacier mass could disappear by 2100 if global warming scenarios in the range of $2-4^{\circ} \mathrm{C}$ indeed occur (Fitzharris et al. 1996; Haeberli, 1995; Haeberli and Beniston, 1998; Kuhn, 1993). The smaller the glacier, the faster it will respond to changes in climate. With an upward shift of 200-300 m in the equilibrium line altitude (ELA, which represents the level below which ablation rates exceed accumulation), the reduction in ice thickness of temperate glaciers could reach 1-2 m per year. As a result, many glaciers in temperate mountain regions would lose most of their mass within decades (Maisch, 1992). Shrinking glaciers will lead to changes in the hydrological response of certain regions compared to today; as glaciers melt rapidly, they will provide enhanced runoff, but as the ice mass diminishes, the runoff will wane. Based on a warming scenario of $3^{\circ} \mathrm{C}$ by 2050 , Maisch (1992) has computed the rise in the ELA for several glaciers in the Swiss Alps. Using computer imaging techniques, he has provided a visual rendering of what a typical glaciated region may look like following the extensive glacier retreat that would occur for the Tschierva Glacier in south-eastern Switzerland, as illustrated in Figure 2. 
Because mountains are the source region for over $50 \%$ of the globe's rivers, the impacts of climatic change on hydrology are likely to have significant repercussions not only in the mountains themselves but also in populated lowland regions that depend on mountain water resources for domestic, agricultural, energy and industrial purposes. Water resources for populated lowland regions are influenced by mountain climates and vegetation; snow feeds into the hydrological basins and acts as a control on the timing of water runoff in the spring and summer months. Hydrological systems are also controlled by soil moisture, which largely determines the distribution of ecosystems, groundwater recharge, and runoff; the latter two factors sustain river flow and can lead to floods.

Significant shifts in climatic conditions will also have an effect on social and economic systems in many regions through changes in demand, supply, and water quality. In regions which are currently sensitive to water stress (arid and semi-arid mountain regions), any shortfalls in water supply will enhance competition for water use for a wide range of economic, social, and environmental applications. In the future, such competition will be sharpened as a result of larger populations, leading to heightened demand for irrigation and perhaps also industrialization, at the expense of drinking water (Noble and Gitay, 1998). Armed disputes over water resources may well be a significant social consequence in an environment degraded by pollution and stressed by climatic change (Glantz, 1988; Beniston, 2002).

Because of increasing population, additional demand will be accompanied by a sharp decline in water availability per capita. A consumption of $1,000 \mathrm{~m}^{3}$ of water per year, per capita is considered a standard for "well-being" in the industrialized world. Projections of annual water availability per capita within the next 20 years, however, show a declining trend in many parts of the world, including those that are considered to have ample water resources (Shiklomanov, 2001). Figure 3 illustrates the problem for several African mountain countries: the changes projected between current and future water availability is a reflection of a combined influence of environmental change (e.g., modified precipitation patterns in a changing climate) and socioeconomic trends (e.g., sustained population growth in many of these countries, implying a reduction in per capita availability even if climate does not change). In many instances, the impact of population growth may in fact be larger than that of climatic change by itself, the latter being merely an exacerbating factor (IPCC, 1998).

\section{Insert Figure 3 here}

The situation is very similar in Latin America, which accounts for 35\% of global non-cryosphere freshwater. The impacts of climatic change are expected to occur in the more arid regions of the continent, which tend to be associated with the rain-shadow influences of the Andes ranges (IPCC, 1998). Shifts in water demands will depend on population growth, industrial expansion, and agricultural potential. The IPCC (1998) estimates that water availability per capita and per annum will decrease from 4,750 $\mathrm{m}^{3}$ in 1990 to 2,100 $\mathrm{m}^{3}$ in Mexico by 2025, without any change in climate, i.e., due to population and economic growth. Based on several GCM simulations, projected shifts in precipitation in a warmer climate yield a range of $1,740-2,010 \mathrm{~m}^{3}$. For Peru, the respective set of figures are $1,860 \mathrm{~m}^{3}, 880 \mathrm{~m}^{3}$ resulting from population growth alone, and 690 - $1,020 \mathrm{~m}^{3}$ with climatic change, i.e., close to or below the minimum requirements for "wellbeing”.

Water resources in southern and tropical Asia, where almost half the world's population resides, are sensitive to tropical cyclones and fluctuations in the trajectories and intensities of these 
systems. The timing of peak runoff, associated with the Monsoon in many tropical Asian river basins, may experience changes in the future. Current runoff in the Ganges, for example, increases six-fold during the Monsoon peak period compared to flows during the dry season. As elsewhere in the world, water resources may become increasingly vulnerable to increasing population growth, urbanization, industrial development and agriculture, as shown by Schreier and Shah (1996). An impacts assessment study by Mirza (1997) for a number of Himalayan basins contributing to the Ganges has shown that changes in mean runoff in different sub-basins ranged from 27 to $116 \%$ in a climate forced by a doubling of $\mathrm{CO}_{2}$ concentrations relative to their pre-industrial levels. Shifts in the timing and intensity of the Monsoon, and the manner in which the Himalayan range intercepts the available precipitable water content of the atmosphere, will have major impacts on the timing and amount of runoff in river basins such as the Ganges, the Brahmaputra or the Irrawaddy. Stephenson et al. $(1998 ; 1999)$ suggest that it is not the strength of the Monsoon that is important in terms of water resources in southern Asia, but rather the failure of the Monsoons. When the Monsoon fails, there may be precipitation shortfalls of over 30\%, leading in turn to devastating droughts and the failure of many crops. Deficient Monsoons include the severe 1877 event, and more recently, events during 11 non-consecutive years since 1950 . While India can weather one such event, two or three successive events may lead to severe damage to the rural economy of the sub-continent.

\subsection{Natural ecosystems}

Plant life at high elevations is primarily constrained by direct and indirect effects of low temperatures, radiation, wind and storminess or insufficient water availability (Körner and Larcher, 1988). Plants respond to these climatological influences through a number of morphological and physiological adjustments such as stunted growth forms and small leaves, low thermal requirements for basic life functions, and reproductive strategies that avoid the risk associated with early life phases.

Because temperature decreases with altitude by $5-10^{\circ} \mathrm{C} / \mathrm{km}$, a first-order approximation regarding the response of vegetation to climate change is that species will migrate upwards to find climatic conditions in tomorrow's climate which are similar to today's (e.g., McArthur, 1972; Peters and Darling, 1985). According to this paradigm, the expected impacts of climate change in mountainous nature reserves would include the loss of the coolest climatic zones at the peaks of the mountains and the linear shift of all remaining vegetation belts upslope. Because mountain tops are smaller than bases, the present belts at high elevations would occupy smaller and smaller areas, and the corresponding species would have reductions in population and may thus become more vulnerable to genetic and environmental pressure (Peters and Darling, 1985; HansenBristow et al., 1988; Bortenschlager, 1993). However, the migration hypothesis may not always be applicable because of the different climatic tolerance of species involved, including genetic variability between species, different longevities and survival rates, and the competition by invading species (Dukes and Mooney, 1999).

Huntley (1991) suggests that there are three responses that can be distinguished at the species level, namely genetic adaptations, biological invasions through species inter-competition, and species extinction. Adaptation pathways in the face of changing environmental conditions include the progressive replacement of the currently dominant species by a more thermophilous (heatloving) species. Observations in the European Alps (Grabherr et al., 1994; Keller et al., 1999) suggest that certain plants are already responding in this manner to observed $20^{\text {th }}$ century warming. A further mechanism is that the dominant species is replaced by pioneer species of the same community that have enhanced adaptation capability (Halpin, 1994; Pauli et al., 1998). A 
third possibility is that environmental change may favor less dominant species, which then replace the dominant species through competition (Street and Semenov, 1990). These scenarios are based on the assumption that other limiting factors such as soil type or moisture will remain relatively unaffected by a changing environment.

It is expected that, on a general level, the response of ecosystems in mountain regions will be most important at ecoclines (the ecosystem boundaries if these are gradual), or ecotones (where step-like changes in vegetation types occur). Guisan et al. (1995) note that ecological changes at ecoclines or ecotones will be amplified because changes within adjacent ecosystems are juxtaposed. In steep and rugged topography, ecotones and ecoclines increase in quantity but decrease in area and tend to become more fragmented as local site conditions determine the nature of individual ecosystems. Even though the timberline is not a perfect ecocline in many regions, it is an example of a visible ecological boundary that may be subject to change in coming decades. This change could either take place in response to a warmer climate, or as a result of recolonization of pastures that have been cleared in the past for pastoral activities. McNeely (1990) has suggested that the most vulnerable species at the interface between two ecosystems will be those that are genetically poorly adapted to rapid environmental change. Those that reproduce slowly and disperse poorly, and those which are isolated or are highly specialized, will therefore be highly sensitive to seemingly minor stresses.

Not all ecotones necessarily respond to change, however. Some boundaries may not be sensitive to climatic change (Körner, 1998; Bugmann and Pfister, 2000), while others may respond with very long lag times (Davis, 1989). There are instances where ecotones are the result of disturbance rather than climate. For example, the current level of many forests in the European Alps is lower than its potential limit because of pastoral practices; in such cases, ecotones may be the drivers of local climatic gradients rather than the contrary (Becker and Bugmann, 2001).

In regions where climatic change may lead to warmer and drier conditions, mountain vegetation could suffer as a result of increased evapotranspiration. This is most likely to occur in mountain climates under the influence of continental and Mediterranean regimes. Even in tropical regions, however, there are indications that plants are already sensitive to water stress on mountains such as Mt. Kinabalu in the Malaysian part of Borneo (Kitayama, 1996).

The length and depth of snow cover, often correlated with mean temperature and precipitation, is one of the key climatic factors in alpine ecosystems (Körner, 1999; Ozenda, 1985; Burrows, 1990). Snow cover provides frost protection for plants in winter, and water supply in spring. Alpine plant communities are characterized by a very short growing season (i.e., the snow-free period) and require water to begin their growth cycle. Ozenda and Borel (1991) have shown that vegetation communities which live in snow beds and in hollows will be the most vulnerable to change, because they will be subject to summer desiccation.

In terms of forest ecosystems, a number of modeling studies have been conducted using forest gap models (Shugart, 1984) to assess the impacts of climatic change on forest biomass and species composition in mountainous regions (Bugmann and Fischlin, 1994). VEMAP, a continental-scale vegetation response study of the United States, considered how three bio-geographical models (BIOME2, DOLY, MAPSS) respond to a double- $\mathrm{CO}_{2}$ scenario. Simulated alpine and sub-alpine regions in the Western US migrate to higher elevations, and thus decrease in area, while subalpine montane forest boundaries also move upward (Woodward et al., 1995). Using gap model simulations applied to British Columbian mountains, Cumming and Burton (1996) have shown that certain upward-moving forest ecosystems could actually disappear from their potential habitats because of the lack of winter cooling, vital for regeneration and the robustness of trees, 
and a greater sensitivity to droughts and frosts. In all forest impacts studies, both in latitudinal and altitudinal terms, climatic change as projected by the IPCC (2001) will be more rapid than the migration capacity of forests. The faster the rate of environmental change, the greater the probability of species extinction and the disruption of ecosystems (Halpin, 1994).

Kienast et al. (1998) have applied a spatially-explicit static vegetation model to alpine vegetation communities. The model suggests that forests which are distributed in regions with low precipitation and on soils with low water storage capacity are highly sensitive to shifts in climate. Under conditions of global warming, the northward progression of Mediterranean influences would probably be important, and it is estimated that $2-5 \%$ of currently forested areas of Switzerland could undergo a steppe-like transition, particularly on the Italian (south-facing) side of the Alps and in the drier intra-alpine valleys. In boreal latitudes, migration of the treeline polewards into previously barren regions would significantly modify the surface characteristics and local climates, in particular through changes in albedo and surface energy balance (Fitzharris et al., 1996). With the expansion of boreal forest zones in both mountain and lowland regions, new assemblages of plant and animal species can be expected in regions such as the northern Alaskan ranges and the eastern Siberian mountains (e.g., Myneni et al., 1999).

Fire is an element that is of particular importance in many ecological systems; it is destructive in numerous circumstances, but also plays a valuable role in the recycling of organic material and the regeneration of vegetation. Changing climatic conditions are likely to modify the frequency of fire outbreaks and intensity, but there are other factors that need to be considered as well. For example, changes in fire-management practices and forest dieback can lead to a weakening of the trees in response to external stress factors (Fosberg, 1990; King and Neilson, 1992). In North America in particular, fire management favored the suppression of forest fires in recent decades, and as a consequence, there has been a substantial increase in biomass compared to natural levels. Stocks et al. (2001) have shown that, under such circumstances, forests tend to transpire most of the available soil moisture, so that catastrophic fires can occur as a result of the greater sensitivity of trees to seemingly minor changes in environmental conditions. One example of the combination of deadwood accumulation resulting from fire-suppression policies and a prolonged drought, is the long and spectacular fire outbreak that occurred in Yellowstone National Park in the United States during the summer of 1988.

With climatic change as projected by the IPCC (2001), prolonged periods of summer drought would transform areas already sensitive to fire into regions of sustained fire hazard. The coastal ranges of California, the Blue Mountains of New South Wales (Australia), Mt. Kenya, and mountains on the fringes of the Mediterranean Sea, already subject to frequent fire episodes, would be severely affected. In addition, many of these regions are located close to major population centers, so that considerable damage to infrastructure and disturbances to economic activities at the boundaries of many large urban areas might be expected. Cities such as Los Angeles and the San Francisco Bay Area in California, Sydney Australia, coastal resorts close to the mountains in Spain, Italy, and southern France could become more vulnerable in the future as fire hazards increase in response to climatic change, and as urban centers expand in response to population pressures. Fires could also break out in regions that are currently relatively unaffected, as critical climatic, environmental, and biological thresholds for fire outbreaks are exceeded (e.g., Johnson, 1992).

\subsection{Human health: the particular case of malaria}


The occurrence of vector-borne diseases such as malaria is determined by the abundance of vectors and intermediate and reservoir hosts, the prevalence of disease-causing parasites and pathogens suitably adapted to the vectors, and the human or animal hosts and their resilience in the face of the disease (McMichaels and Haines, 1997). Local climatic conditions, especially temperature and moisture, are also determinant factors for the establishment and reproduction of the Anopheles mosquito (Epstein et al., 1998). The possible development of the disease in mountain regions thus has relevance, because populations in uplands where the disease is currently not endemic may face a new threat to their health and well-being as malaria progressively invades new regions under climatic conditions favorable to its development. (Martens et al., 1999).

The occurrence of vector-borne diseases is widespread, ranging from the tropics and subtropics to the temperate climate zones. With few exceptions, they do not occur in the cold climates of the world, and are absent above certain altitudes even in mountain regions of the tropical and equatorial belt (WHO, 1999). At elevations above 1,300 - 1,500 m in Africa and tropical Asia, the Anopheles mosquito can currently neither breed nor survive; as a result, malaria is almost totally absent from many highlands of the tropical zone (Craig et al., 1999).

Vectors require specific ecosystems for survival and reproduction. These ecosystems are influenced by numerous factors, many of which are climatically-controlled. Changes in any of these factors will affect the survival and hence the distribution of vectors (Kay et al., 1989). Global climatic change projected by the IPCC (2001) may have a considerable impact on the distribution of vector-borne diseases. A permanent change in one of the abiotic factors may lead to an alteration in the equilibrium of the ecosystem, resulting in the creation of either more or less favorable vector habitats. At the present limits of vector distribution, the projected increase in average temperature is likely to create more favorable conditions, both in terms of latitude and altitude for the vectors, which may then breed in larger numbers and invade formerly inhospitable areas.

The infection rate for malaria is an exponential function of temperature (WHO, 1990); small increases in temperature can lead to a sharp reduction in the number of days of incubation. Regions at higher altitudes or latitudes may thus become hospitable to the vectors; disease-free highlands that are today found in parts of Ethiopia and Kenya, for example, may be invaded by vectors as a result of an increase in the annual temperature. If this were to occur, then the number of persons infected by malaria would increase sharply.

Lindsay and Martens (1998) and Martens et al. (1999) have investigated the possible changes in the distribution of malaria. Increases in temperature and rainfall would most probably allow malaria vectors to survive in areas immediately surrounding their current distribution limits. How far these areas will extend both in terms of altitude and latitude depends upon the extent of warming. The IPCC (1998) has published maps of increases in the incidence of malaria in Africa, as given in Figure 4 for a modest warming scenario of $+1^{\circ} \mathrm{C}$. It is seen that the regions with the sharpest rise in the rate of infection are those which lie above 1,000 $\mathrm{m}$ (as given in the inset map). In these highland regions, even a modest rise in temperature may lead to a spread of the disease into hitherto disease-free regions. Figure 5 illustrates that the trend may already be discernible in a number of highland regions of Africa, such as Zambia and Rwanda (Loevinsohn, 1994). It is seen here that there is a quasi-exponential increase in the incidence of malaria, which is, at least in part, consecutive to changing climatic conditions for the period 1975-1990.

Insert Figure 4 here 


\section{Insert Figure 5 here}

This conclusion is in apparent contradiction to a number of studies that attempt to play down any clearly discernible link between observed climatic change and increases in malaria in the East African highlands. One recent study by Hay et al. (2002) concludes that, at least for Kenyan uplands, there have been no climatic trends of sufficient importance for transmission of the disease during the $20^{\text {th }}$ century. The authors furthermore state that because of the high spatial and temporal variability of East African climate, "claimed associations between local malaria resurgences and regional changes in climate are overly simplistic". While this may indeed be a logical conclusion for the relatively modest changes in climate observed in the region, it may not hold when changes are of greater amplitude. A particular example is the intensification of malaria in Colombia during episodes of El Niño, whereby mean temperatures increase and mean precipitation decreases with respect to normal conditions (Poveda et al., 2001). Such links between abrupt but significant changes in climate and the annual cycle of malaria development and transmission may help further our understanding of the links between environmental and epidemiological factors, both on the short term (ENSO cycles) and the longer term (climatic change).

Africa is not the only continent to be affected by the increase in vector-borne diseases; in certain countries where the disease has been eradicated in the second half of the $20^{\text {th }}$ Century, particular strains of malaria are resurging. There are reports from various low to medium elevation upland sites in Turkey, Tajikistan, Uzbekistan, Turkmenistan and the Urals that malaria is being transmitted in rural populations, with close to epidemic proportions in south-eastern Anatolia (Wilson et al., 2001).

It is often difficult to associate any particular change in the incidence of a particular disease with a given change in a single environmental factor. It is necessary to place the environment-related health hazards in a population context, such as age, level of hygiene, socio-economic level, and health status (McMichaels and Kovats, 2000). These phenomena could contribute to migration from one rural region to another and from rural to urban areas (Myers, 1993). In addition, if climatic change were to be accompanied by an increase in the intensity of certain forms of natural hazards, such as cyclones, floods, or drought, these would compound the effects on human health. Moreover, such catastrophes can generate large refugee and population movements, with a need for resettlement in what are often already densely populated areas (Pebley, 1998).

Forecasting the climate change impacts on health is complex, because populations have different vulnerabilities to change and susceptibility to disease. These depend on the general levels of hygiene practices, clothing, housing, medical and agricultural traditions. Adaptation of populations to the spread of malaria and other vector-borne diseases is determined by the economic level of a given population, the quality and coverage of medical services, and the integrity of the environment. There are numerous side-effects of environmental change that can impact upon health and well-being, including hygrothermal stress and enhanced levels of air pollution. While these aspects are not in themselves exclusive to mountain regions, however, many of the changes will have indirect effects by modifying natural ecosystems, affecting such aspects as food production, vector-borne diseases, and the equilibrium between a number of other infectious and non-infectious diseases (McMichaels and Kovats, 2000).

\subsection{Tourism}


Tourism is an industry that has exhibited the most sustained growth of any global industry in the last 25 years. It accounts for $10 \%$ of the world's net financial output, with many countries in the developing world dependent on tourism as their main source of income. In the developing countries, tourism of all types contributes roughly US\$ 50 billion annually (Perry, 2000). Figures released by the World Tourism Organization (WTO, 2000) indicate that the number of international tourists has increased 25-fold in the second half of the $20^{\text {th }}$ Century.

Patterns of tourism have become more diversified, with new activities added to more traditional recreational activities and destinations. As a consequence, even remote natural areas, in particular mountain regions in the Himalayas, the Andes and East Africa, are attracting increasing numbers of tourists, with a parallel boom in the development of tourism infrastructure and construction. This infrastructure is often located in attractive cultural and natural landscapes, often with negative impacts for those landscapes and the sensitive ecosystems that they support (Godde et al., 2000). Tourism is thus both a significant economic driver for many mountain communities, but also an industry capable of adversely affecting the environmental quality of mountains and uplands.

Climate change is likely to have both direct and indirect impacts on tourism in mountain areas. Direct impacts refer to changes in the climatic conditions necessary for specific activities. Indirect changes may result from both changes in mountain landscapes (referred to by Krippendorf, 1984, as the "capital of nature)", and wider-scale socio-economic changes such as patterns of demand for specific activities or destinations (Price, 1990). Using scenarios derived from GCMs, a number of investigations have been carried out to examine the possible implications of climate change for skiing in Australia (Galloway, 1988), eastern Canada (Lamothe and Périard, 1988), and Switzerland (Abegg et al., 1997; Koenig and Abegg, 1997). Abegg and Froesch (1994) showed in their study of the Swiss ski industry that if temperatures were to rise by about $2-3^{\circ} \mathrm{C}$ by the year 2050, the low to medium elevation resorts located below 1,200 - 1,500 m above sea level would be adversely affected. Warmer winters bring less snow at these low elevations, and the probability of snow lying on the ground at peak vacation periods (Christmas, February and Easter) would decline. A general rule for the viability of the ski season in Europe is a continuous snow cover of over $30 \mathrm{~cm}$ depth for at least 100 days. Based on these figures, Koenig and Abegg (1997) have shown that whereas in the late $20^{\text {th }}$ Century, $85 \%$ of ski resorts have had reliable amounts of snow for skiing, a $2^{\circ} \mathrm{C}$ warming would bring this figure down to $63 \%$. Regions such as the Jura Mountains in the west of the country, whose average altitude lies between $900-1,200$ $\mathrm{m}$, would experience much-reduced periods with adequate snow-cover, whereas the elevated ski resorts in the central and southern Alps would remain relatively unaffected. Such impacts might be partially offset by new opportunities in the summer season and also by investments in new technology, such as snow-making equipment, as long as climatic conditions remain within appropriate bounds. Mountaineering and hiking may provide compensation for reduced skiing, and thus certain mountain regions would remain attractive destinations. However, global climate change has wider implications for traditional holiday breaks, with destinations other than mountains in winter becoming at least as competitive if not more. Higher temperatures may imply longer summer seasons in mid-latitude countries, and Perry and Smith (1996) suggest that a new range of outdoor activities may emerge as a consequence.

\section{Conclusions}

It seems appropriate to close this review of environmental issues in mountain regions with a summary of the major recommendations for mountain research and conservation. Reference is made to the UN Framework Convention on Climate Change (FCCC), negotiated in the context of 
the UNCED-1992 "world summit", where Chapter 13 of "Agenda 21" also saw its official inception. Article 2 of the UN FCCC stipulates that:

«...The ultimate objective of the FCCC... is the stabilization of greenhouse gas concentrations in the atmosphere at a level that would prevent dangerous anthropogenic interference with the climate system...Such a level should be achieved within a time-frame sufficient to allow ecosystems to adapt naturally to climate change, to ensure that food production is not threatened and to enable economic development to proceed in a sustainable manner...»

The problem in interpreting this Article is that a relatively modest level of climatic change may have little or no impact on certain ecosystems, while others may face extinction at that particular level of change. In this case, the question that arises is whether all ecosystems should be protected, in which case anthropogenic climate change would need to remain confined within the bounds of natural climatic variability. If only selected ecosystems were to be protected, then it would be essential to determine the thresholds of vulnerability beyond which damage may become irreversible. In many cases, vulnerability thresholds are poorly known, in part because the functioning of plants has for the most part been studied only in contemporary environments and climates. There are also ethical issues to be addressed when determining which priority needs to be given to the protection of a particular species or ecosystem.

Because mountain ecosystems are often referred to as "hotspots of biodiversity" (Price et al., 2000), they warrant protection in order to maintain ecosystem integrity and adaptability. Furthermore, montane vegetation is important in terms of its protective role against slope erosion and as a component of mountain hydrology and water quality. Whatever the ecosystem response to multiple environmental stress factors, adaptation of natural ecosystems to climatic change in many regions cannot be achieved without some kind of human intervention, in the form of ecosystem management. Reforestation would in some cases be a viable adaptation option, and so would afforestation of abandoned agricultural land. Freshwater biological systems can be assisted in a number of ways which could help mitigate the impacts of climate change, particularly through the increase and protection of riparian vegetation, and restoring river and stream channels to their natural morphologies.

One approach to ecosystem conservation in mountains and uplands is the setting up of refugia and migration corridors. Refugia are buffer-zones that can play the role of allowing ecosystems to adapt or migrate to change. National parks with restricted access, and biosphere reserves are one form of refugia. In some instances, however, biospheric reserves may be too small to be effective. A recent study by Zimmermann and Kienast (1999) have shown that in the Swiss National Park (an area of $200 \mathrm{~km}^{2}$ located in the south-eastern part of the country), almost $50 \%$ of the migrating species would be unable to be hosted because of the limited vertical extension of the park. Another major problem in many parts of the European Alps and other populated mountain regions is that ecosystems have been so fragmented and the population density is so high, that many options may be impossible to implement. In addition, various assessment studies have shown that the establishment of refugia in many parts of the world would result in increasing conflicts between economic development and environmental concerns (Chapter 13 of Agenda 21).

Suggested research topics include an intercomparison of key physical and biological processes in different mountains of the world, the establishment of a global mountain database that would include images, statistics on environmental change (glaciers, vegetation, land-use, etc.), the promotion of research on systems under threat, such as montane cloud forests, and the recognition of, and strategies for, new health hazards in mountains. Concern over the possible 
migration of populations in response to adverse climatic and other environmental pressures is also a theme that needs to be addressed, according to the IYM.

Becker and Bugmann (2001) have outlined suggested strategies for research under the auspices of the International Geosphere-Biosphere Program (IGBP), the International Human Dimensions Program (IHDP) and the Global Terrestrial Observing System (GTOS), in a coordinated scheme known as the Mountain Research Initiative MRI. In this context, four main research activities and tasks have been put forward, namely:

- Long-term monitoring and analysis of indicators of environmental change in mountain regions, with a particular focus on cryospheric indicators, watershed hydrology, and terrestrial and acquatic ecosystems;

- Integrated model-based studies of environmental change in different mountain regions, in particular coupled ecological, hydrological and land-use models, models allowing the study of feedbacks between land surfaces and the atmosphere, and integrated (physical, biological and economic) analyses of environmental change for policy purposes;

- Process studies along altitudinal gradients and in associated headwater basins; such studies allow an assessment of environmental change at ecological and climatological boundaries, and thus the sensitivity of vegetation, snow, ice, and water resources to a range of forcings;

- Sustainable land-use and natural resource management, with priorities for changes in forest resources, shifts in mountain agriculture and food security, and modifications to water resources driven by economic and demographic factors.

These diverse research and education initiatives, beyond their intrinsic value, also have the objective of feeding into the policy sphere. According to the outcome of ongoing and future research, policy response should lead to coordinated action by UN, governmental and nongovernmental organizations in favor of environmental protection in mountains and uplands, and to help local populations adapt to changing ecological, economic, and health-related impacts. Policy should also aim to convince key global actors such as the World Trade Organization (WTO) to take mountain issues into consideration in the planning of future trade accords and commercial practices. Furthermore, a strengthening of ties between the "mountain chapter" of Agenda 21 and the UN Conventions on Climate Change, Biodiversity, and Desertification may lead to a more efficient, holistic approach to the problems currently facing many mountain regions.

Many of the objectives of the IYM and the IGBP/IHDP/GTOS "Mountain Research Initiative" are ambitious and, in some instances, in apparent contradiction to current non-sustainable economic policies. Since the publication of Agenda 21, the recognition of the importance of mountain regions in numerous ecological, social and economic sectors has steadily gained ground. The momentum generated by IYM should help in the long-term protection of mountain environments and the quality of the goods and services that they provide, and in the formulation of appropriate adaptation and mitigation strategies in the face of climatic change in the course of the $21^{\text {st }}$ century.

\section{References}

Abegg, B., and R. Froesch, 1994: Climate change and winter tourism: impact on transport companies in the Swiss Canton of Graubünden. In: Beniston, M. (ed.), Mountain environments in changing climates. Routledge Publishing Company, London and New York, pp. 328-340 
Abegg, B., Koenig, U., Burki, R., and Elsasser, H., 1997: Climate impact assessment in tourism. Die Erde, 128, 105116

Arnell, N., 1999: The effect of climate change on hydrological regimes in Europe. Global Environmental Change, 9, 523

Becker, A. and Bugmann, H. (eds.), 1997: Predicting Global Change Impacts on Mountain Hydrology and Ecology: Integrated Catchment Hydrology/Altitudinal Gradient Studies. IGBP Report 43, Stockholm

Becker, A., and Bugmann, H. (eds.), 2001: Global Change and Mountain Regions. The Mountain Research Initiative. IGBP Report 49, Stockholm

Beniston, M. (ed), 2002: Climatic change. Implications for the hydrological cycle and for water management. Advances in Global Change Research, Kluwer Academic Publishers, Dordrecht and Boston, 503 pp.

Beniston, M., 1997 : Variations of snow depth and duration in the Swiss Alps over the last 50 years : links to changes in large-scale forcings. Climatic Change, 36, 281-300

Beniston, M., 2000 : Environmental Change in Mountains and Uplands. Arnold Publishers, London, and Oxford University Press, New York, 172 pp.

Beniston, M., and Jungo, P., 2001: Shifts in the distributions of pressure, temperature and moisture in the alpine region in response to the behavior of the North Atlantic Oscillation. Theor. and Appl. Clim., 71, 29-42

Beniston, M., and Rebetez, M., 1996: Regional behavior of minimum temperatures in Switzerland for the period 1979 1993. Theor. and Appl. Clim. 53, 231 - 243

Beniston, M., Diaz, H. F., and Bradley, R. S., 1997: Climatic change at high elevation sites; a review. Climatic Change, 36, $233-251$

Bergström, S., Carlsson, B., Gardelin, M., Lindström, G., Pettersson, A. and Rummukainen, M., 2001: Climate change impacts on runoff in Sweden - assessments by global climate models, dynamical downscaling and hydrological modelling. Climate Research 16, 101-112

Bortenschlager, S., 1993: Das höchst gelegene Moor der Ostalpen "Moor am Rofenberg" 2760 m. Festschrift Zoller, Diss. Bot., 196, 329-334.

Bugmann, H., and A. Fischlin, 1994: Comparing the behaviour of mountainous forest succession models in a changing climate,. In: Mountain Environments in Changing Climates, M. Beniston, (ed.), Routledge Publishing Company, London and New York, 204-219

Bugmann, H., and Pfister, C., 2000: Impacts of interannual climate variability on past and future forest composition. Regional Environmental Change, 3/4, 112-125

Burrows, C.J, 1990: Processes of Vegetation Change, Unwin Hyman Publishing, London, 551

Cayan, D.R., S.A. Kammerdierner, M.D. Dettinger, J.M. Caprio, and D.H. Peterson, 2001: Changes in the onset of spring in the western United States. Bull. Amer. Meteorol. Soc., 82, 399-415.

Chinn, T. 1996. New Zealand glacier responses to climate change of the past century. New Zealand Journal of Geology and Geophysics 39, 415-428

Craig, M. H., Snow, R. W., and LeSueur, D., 1999: A climate-based distribution model of malaria transmission in Africa. Parasitology Today, 15, 105-111

Cumming, S.G. and P.J. Burton, 1996 : Phenology-mediated effects of climatic change on some simulated British Columbia forests. Climatic Change, 34(2), 213-222

Davis, M. B., 1989: Lags in vegetation response to greenhouse warming. Climatic Change, 15, 75-82

Dettinger. M.D., Cayan, D.R., Diaz, H.F., and Stewart, I., 2002: Variations and trends in snowmelt and streamflow timing; global and North American patterns in the $20^{\text {th }}$ century. This volume, Chapter 4

Dukes, J. S., and Mooney, H. A., 1999: Does global change increase the success of biological invaders? Trends in Ecology and Evolution, 14, 135-139

Epstein, P. R., Diaz, H. F., and Elias, S., 1998:. Biological and physical signs of climate change. Focus on mosquitoborne diseases. Bull Am Meteorol Soc, 78, 410-417

Fitzharris, B. B., Allison, I., Braithwaite, R.J., Brown, J., Foehn, P., Haeberli, W., Higuchi, K., Kotlyakov, V.M., Prowse, T.D., Rinaldi, C.A., Wadhams, P., Woo, M.K., Youyu Xie, 1996: The Cryosphere: Changes and their impacts. In: Second Assessment Report of the Intergovernmental Panel on Climate Change (IPCC), Chapter 5, Cambridge University Press, pp. 241-265

Fosberg, M.A., 1990 : Global change - a challenge to modeling. In : Process modeling of forest growth responses to environmental stress Dixon, R.K., R.S. Meldahl, G.A. Ruark, and W.G. Warren (eds.). Timber Press, Inc., Portland, OR, USA, pp. 3-8.

Frei, C., Schär, C., Lüthi, D., and Davies, H.C., 1998: Heavy precipitation processes in a warmer climate. Geophys. Res. Lett., 25, 1431-1434

Galloway, R.W., 1988: The potential impact of climate changes on Australian ski fields, Greenhouse Planning for Climate Change, G.I. Pearman, (ed.), CSIRO, Aspendale, Australia, 428-437

Giorgi, F., and Mearns, L.O., 1991: Approaches to the simulation of regional climate change. Rev. Geoph., 29, 191216.

Giorgi, F., and Mearns, L. O., 1999: Regional climate modeling revisited. J. Geophys. Res., 104, 6335-6352

Giorgi, F., Hurrell, J., Marinucci, M., and Beniston, M., 1997: Height dependency of the North Atlantic Oscillation Index. Observational and model studies. J. Clim., 10, 288 - 296 
Glantz, M.H., (ed.), 1988: Societal Responses to Regional Climatic Change, Westview Press, Boulder, Colorado.

Godde, P., Price, M.F. and Zimmermann, F.M. (eds.), 2000: Tourism and Development in Mountain Regions. CABI Publishing, Wallingford

Goyette, S., Beniston, M., Jungo, P., Caya, D., and Laprise, R., 2001: Numerical investigation of an extreme storm with the Canadian Regional Climate Model: The case study of windstorm Vivian, Switzerland, February 27, 1990. Climate Dynamics, 18, 145-168

Grabherr, G., M. Gottfried, and H. Pauli, 1994: Climate effects on mountain plants, Nature, 369, 448.

Guisan, A., J. Holten, R. Spichiger, and L. Tessier, (eds.), 1995: Potential Impacts of Climate Change on Ecosystems in the Alps and Fennoscandian Mountains. Annex Report to the IPCC Working Group II Second Assessment Report, Publication Series of the Geneva Conservatory and Botanical Gardens, University of Geneva, Switzerland, 194 pp.

Haeberli, W., 1995: Glacier fluctuations and climate change detection - operational elements of a worldwide monitoring strategy. WMO Bulletin 44, 1, 23 - 31.

Haeberli, W., and Beniston, M., 1998: Climate change and its impacts on glaciers and permafrost in the Alps. Ambio, 27, $258-265$

Halpin, P.N., 1994: Latitudinal variation in montane ecosystem response to potential climatic change, M. Beniston, (ed.), Mountain Ecosystems in Changing Climates, Routledge Publishing Company, London and New York, 180-203.

Hansen-Bristow, K.J., Ives, J.D., and Wilson, J.P., 1988: Climatic variability and tree response within the forest-alpine tundra ecotone, Annals of the Association of American Geographers, 78, 505-519.

Hastenrath, S and Greischar, L., 1997. Glacier recession on Kilimanjaro, East Africa, 1912-89. Journal of Glaciology 43 (145), 455-459

Hay, S. I., Cox, J., Rogers, D. J., Randolph, S. E., Stern, D. I., Shanks, D. G., Myers, M. F., and Snow, R. W., 2002 : Climate change and the resurgence of malaria in the East African highlands. Nature, 415, 905-909

Hedberg, O., 1964: The phytogeographical position of the afroalpine flora, Recent Adv. in Bot., 914-919.

Hodge, S.M., Trabant, D.C., Krimmel, R.M., Heinrichs, T.A., March, R.S., and Josberger, E.G., 1998: Climate variations and changes in mass of three glaciers in western North America. Journal of Climate 11, 2161-2179

Huntley, B. 1991: How plants respond to climate change: migration rates, individualism and the consequences for plant communities, Annals of Botany, 67, 15-22.

Hurrell, J. W., and van Loon, H., 1997 : Decadal variations in climate associated with the North Atlantic Oscillation. Climatic Change, 36, 301-326

IPCC, 1996: Climate Change. The IPCC Second Assessment Report. Cambridge University Press, Cambridge and New York. Volumes I (Science), II (Impacts) and III (Socio-economic implications)

IPCC, 1998: The regional impacts of climate change. Cambridge University Press, Cambridge and New York, 517 pp.

IPCC, 2001: Climate Change. The IPCC Third Assessment Report. Cambridge University Press, Cambridge and New York. Volumes I (The Scientific Basis), II (Impacts, Adaptation, and Vulnerability) and III (Mitigation)

Johnson, E. A., 1992: Fire and vegetation dynamics. Studies from the North American boreal forest. Cambridge University Press, Cambridge.

Jones, P.D., Jónsson, T. and Wheeler, D., 1997: Extension to the North Atlantic Oscillation using early instrumental pressure observations from Gibraltar and South-West Iceland. Int. J. Climatol. 17, 1433-1450.

Kapos, V., Rhind, J., Edwards, M., Ravilious, C., and Price, M., 2000: Developing a map of the world's mountain forests. In: Price, M.F., and Butt, N. (eds.), Forests in a sustainable mountain environment. CAB International, Wallingford.

Kay, B.H. et al., 1989: Rearing temperature influences flavivirus vector competence of mosquitoes. Med. Vet. Entomol., 3, 415-422.

Keller, F., Kienast, F., and Beniston, M., 2000: Evidence of the response of vegetation to environmental change at high elevation sites in the Swiss Alps. Regional Env. Change, 2, 70-77

Kienast, F., Wildi, O., Brzeziecki, B., Zimmermann, N., and Lemm, R., 1998: Klimaänderung und mögliche langfristige Auswirkungen auf die Vegetation der Schweiz. VdF Hochschulverlag, Zurich, 71 pp.

King, G.A. and Neilson, R.P., 1992: The transient response of vegetation to climate change : a potential source of $\mathrm{CO}_{2}$ to the atmosphere. Water, Air and Soil Pollution, 64, 365-383.

Kitayama, K., 1996: Climate of the summit region of Mount Kinabalu (Borneo) in 1992, an El Niño year. Mountain Research and Development, 16(1), 65-75

Koenig, U., and Abegg, B., 1997: Impacts of climate change on winter tourism in the Swiss Alps. Journal of Sustainable Tourism, 5, 46-57

Körner, C. and Larcher, W., 1988: Plant life in cold climates. In: Long, S.F. and Woodward, F.I. (eds.), Plants and temperature. The Company of Biol Ltd, Cambridge, pp. 25-57

Körner, C., 1998: Worldwide positions of alpine treelines and their causes. In: Beniston, M., and Innes, J. L. (eds.), The Impacts of Climate Variability on Forests. Lecture Notes in Earth Sciences, 74, Springer-Verlag, Heidelberg and New York, pp. 221-229

Körner, C., 1999: Alpine Plant Life. Springer-Verlag, Heidelberg and New York, 338 pp. 
Krippendorf, J., 1984: The capital of tourism in danger, The Transformation of Swiss Mountain Regions, E.A. Brugger, et al., (eds.), Haupt Publishers, Bern, 427-450

Kuhn, M., 1993: Possible future contribution to sea-level change from small glacier. In: Warrick, R.A., Barrow, E.M., and Wigley, T.M.L., (Eds.), Climate and sea-level change: Observations, projections and implications. Cambridge University Press, Cambrisge, UK, pp. 134-143

Lamothe, M., and D. Périard, 1988: Implications of climate change for downhill skiing in Quebec, Climate Change Digest, Atmospheric Environment Service, Downsview, 88-103

Lindsay, S. W., and Martens, W. J. M., 1998: Malaria in the African highlands, past, present and future. WHO Bulletin, 76, 33-45

Loevinsohn, M., 1994: Climatic warming and increased malaria incidence in Rwanda. The Lancet, 343, 714-718

Maisch, M., 1992: Die Gletcher Graubündens - Rekonstruktion und Auswertung der Gletscher und deren Veränderungen seit dem Hochstand von 1850 im Gebiet der östlichen Schweizer Alpen (Bündnerland und angrenzende Regionen). Publication Series of the Department of Geography of the University of Zurich, Switzerland.

Marinucci, M. R., Giorgi, F., Beniston, M., Wild, M., Tschuck, P., and Bernasconi, A., 1995: High resolution simulations of January and July climate over the Western Alpine region with a nested regional modeling system. Theor. and Appl. Clim., 51, 119 - 138

Martens, P., Kovats, R. S., and Nijhof, S., 1999: Climate change and future populations at risk from malaria. Global Environmental Change, 9, 89-107

Martin, E., and Durand, Y., 1998: Precipitation and snow cover variability in the French Alps. In: Beniston, M., and Innes, J. L. (Eds.), The Impacts of Climate Change on Forests, Springer-Verlag, Heidelberg/New York, pp. 8192

McArthur, R.H., 1972: Geographical Ecology, Harper and Row, New York.

McMichael, A. J., and Haines, A., 1997: Global climate change: the potential effects on health. British Medical Journal, 315, 805-809

McMichaels, A. J., and Kovats, R. S., 2000: Climate change and climate variability. Adaptations to reduce adverse climate change impacts. Environmental Monitoring and Assessment, 61, 49-64

McNeely, J.A., 1990: Climate change and biological diversity: policy implications, Landscape-Ecological Impact of Climatic Change, M.M. Boer, and R.S. de Groot, (eds.), IOS Press, Amsterdam.

Meier, M., 1998. Land ice on Earth: A beginning of a global synthesis. Unpublished transcript of the 1998 Walter B. Langbein Memorial Lecture, American Geophysical Union Spring Meeting, Boston, MA, 26 May 1998.

Meybeck, M., Green, P., and Vörösmarty, C., 2001: A New Typology for Mountains and Other Relief Classes: An Application to Global Continental Water Resources and Population Distribution. Mountain Research and Development, 21, 34-45

Mirza, M.Q., 1997: The runoff sensitivity of the Ganges river basin to climate change and its implications. Journal of Environmental Hydrology, 5, 1-13.

Mountain Agenda, 2001: Mountains of the World - Mountains, Energy and Transport. Price, M., Kohler, T., Wachs, T., Zimmermann, A. (eds.), Mountain Agenda, Bern, 51 pp.

Myers, N., 1993: Environmental refugees in a globally warmed world. Bioscience, 43, 752-761

Myneni, R. B., Keeling, C. D., Tucker, C. J., Asrar, G., 1999: Increased plant growth in the northern high latitudes from 1981 to 1991. Nature, 386, 698-702

Noble, I., and Gitay, H. : Climate change in desert regions. In : IPCC, 1998, The Regional Impacts of Climate Change, Watson, R. T., Zinyowera, M., and Moss, R. (eds.), Cambridge University Press, pp. 191 - 217

Osborn, T. J., Briffa, K. R., Tett, S. F. B., Jones, P. D., and Trigo, R. M., 1999: Evaluation of the North Atlantic Oscillation as simulated by a coupled climate model. Climate Dynamics, 15, 685-702

Ozenda, P., 1985: La Végétation de la Chaine Alpine dans l’Espace Montagnard Européen, Masson, Paris, 344.

Ozenda, P., and J.-L. Borel, 1991: Les Conséquences Ecologiques Possibles des Changements Climatiques dans l'Arc Alpin. Rapport Futuralp No. 1, International Centre for Alpine Environment (ICALP), Le Bourget-du-lac, France.

Pauli, H., Gottfried, M., and Grabherr, G., 1998: Effects of climate change on mountain ecosystems. Upward shifting of alpine plants. World Resources Review, 8, 382-390

Pebley, A.R., 1998: Demography and the Environment. Demography, 35, 377-389

Perry, A. H., 2000: Impacts of climate change on tourism. In: Parry, M. L. (ed), Assessment of Potential Effects and Adaptations for Climate Change in Europe; the ACACIA Report. Jackson Environment Institute, Norwich, and EU Publications, Brussels, pp.217-226

Perry, A. H., and Smith, K., 1996: Recreation and tourism. In: Department of the Environment, Climate Change Report, London

Peters, R.L., and Darling, J.D.S., 1985: The greenhouse effect and nature reserves: global warming would diminish biological diversity by causing extinctions among reserve species, Bioscience, 35, 707-717 
Poveda, G., Rojas, W., Quinones, M.L., Velez, I.D., Mantilla, R.I., Ruiz, D., Zuluaga, J.S., and Rua, G.I., 2001 : Coupling between annual and ENSO timescales in the malaria-climate association in Colombia. Environ. Health Perspect., 109, 489-493

Price, M.F., 1990: Temperate mountain forests: common-pool resources with changing, multiple outputs for changing communities, Natural Resources Journal, 30, 685-707.

Price M., Kohler, T., and Wachs, T. (eds.), 2000: Mountains of the world: Mountain Forests and Sustainable Development. Paul Haupt Publishers, Bern. 42 pp.

Rotach, M., Wild, M., Tschuck, P., Beniston, M., and Marinucci, M. R., 1996: A double $\mathrm{CO}_{2}$ experiment over the Alpine region with a nested GCM-LAM modeling approach. Theor. and Appl. Clim., 57, 209-227

Schreier, H. and P.B. Shah, 1996 : Water dynamics and population pressure in the Nepal Himalayas. Geojournal, 40(12), 45-51.

Shiklomanov, I. A., (ed), 2001: World water resources at the beginning of the $21^{\text {st }}$ century. UNESCO Publications, Paris

Shugart, H.H., 1984: A Theory of Forest Dynamics. The Ecological Implications of Forest Succession Models. Springer-Verlag, New York, 278 pp

Stephenson, D. B., Chauvin, F., and Royer, J-F., 1998. Simulation of the Asian summer monsoon and its dependence on model horizontal resolution. Journal of the Met. Soc. of Japan, Vol 76, 2, pp. 237-265.

Stephenson, D.B., Rupa Kumar, K., Doblas-Reyes, F.J., Royer, J.-F., Chauvin, F. and Pezzulli, S. 1999: Extreme daily rainfall events and their impact on ensemble forecasts of the Indian monsoon. Monthly Weather Review, 127, 1954-1966Stevens, W, 1989 : Governments Start Preparing for Global Warming Disasters, New York Times (November 14, 1989), p. C1.

Stocks, B. J., Wotton, B. M., Flannigan, M. D., Fosberg, M. A., Cahoon, D. R., and Goldammer, J. G., 2001: Boreal forest fire regimes and climate change. Advances in Global Change Research, 7. Kluwer Academic Publishers, Dordrecht and Boston, pp. 233-246

Street, R.B., and Semenov, S.M., 1990: Natural terrestrial ecosystems. In: Tegart, W.J. KcG., Sheldon, G.W., and Griffiths, D.C. (Eds.), Climate Change: The First Impacts Assessment Report. Australian Government Publishing Service, Chapter 3.

Thompson, L.G., Mosley-Thompson, E. and Henderson, K.A., 2000: Ice core paleoclimate records in tropical South America since the Last Glacial Maximum. Journal of Quaternary Science, 15, 377-394

UN, 1992: Earth Summit: Agenda 21. The United Nations Programme of Action from RioThe final text of agreements negotiated by governments at the United Nations Conference on Environment and Development (UNCED), 314 June 1992, Rio de Janeiro, Brazil. 294 pp.

UN, 1998: Proclamation of the International Year of the Mountains. Report on the 1998 UN General Assembly Meeting, New York. Text and signatories can be accessed via Internet at URL: http://www.mtnforum.org/resources/library/uniym99a.htm

Vuille, M., and Bradley, R. S., 2000: Mean annual temperature trends and their vertical structure in the tropical Andes, Geophys. Res. Lett., 27, 3885-3888

WGMS, 2000: Glacier Mass Balance, Bulletin, W. Haeberli and M. Hoelzle (eds.), World Glacier Monitoring Service, ETH Zurich, Switzerland

Whiteman, D., 2000: Mountain Meteorology. Oxford University Press, 355 pp.

WHO, 1990 : Potential health effects of climatic change. Report of a WHO Task Group. World Health Organization, Geneva

WHO, 1999: World Health Report 1999. World Health Organization, Geneva

Wilson' M. L., Mahanty, B., Wannebo, A., MacDonald, P., Gleason, A., Smith, R., and Aksoy, S., 2001: Vector-borne Disease Associated with Irrigation, Agriculture, and Environmental Change in Southeastern Turkey: Application of Satellite Image Analysis. Yale-New Haven Medical Center Report 
Woodward, F.I., Smith, T.M., Emanuel W.R., 1995: A global primary productivity and phytogeography model. Global Biogeochem. Cycles, 9, $471-490$

WTO, 2000: Compendium of Tourism Statistics, Year 2000 Edition. World Tourism Organization Publications, Madrid, 235 pp

Zimmermann, N., and Kienast, F. 1999: Predictive mapping of alpine grasslands in Switzerland: Species versus community approach. Journal of Vegetation Science 10, 469-482.

Zorita, E. and H. von Storch, 1999: The analog method - a simple statistical downscaling technique: comparison with more complicated methods. J. Climate 12: 2474-2489 


\section{Figure Captions}

Figure 1: Response of mean winter-season temperature distribution at the high elevation site of Saentis (2,500 m above sea-level, in the north-eastern Swiss Alps) to opposing behavior of the North Atlantic Oscillation index, based on the Jones et al. (1997) data set.

Figure 2: GIS-based modeling of the extent of glacier retreat expected for the Tschierva Glacier (Grisons, south-eastern Switzerland) in response to a $3^{\circ} \mathrm{C}$ warming. Courtesy: Max Maisch, University of Zurich, Switzerland.

Figure 3: Water availability in certain African upland countries in 1990 and as projected for 2025, based on estimates for population growth and climatic change (IPCC, 1998)

Figure 4: Changes in the incidence rate of malaria in Africa, following a modest $1^{\circ} \mathrm{C}$ average temperature increase. Gray scale denotes invasion of the vector into currently malaria-free regions. Inset map highlights African highland regions above $1,000 \mathrm{~m}$; note that the spread of malaria is likely to occur because these upland regions will become increasingly hospitable to the Anopheles mosquito as climate warms(IPCC, 1998).

Figure 5: Infection rate in two African highland countries (Rwanda and Zambia), 1975-1990 (Loevinsohn, 1994) 
Beniston, 2002 : Climatic Change

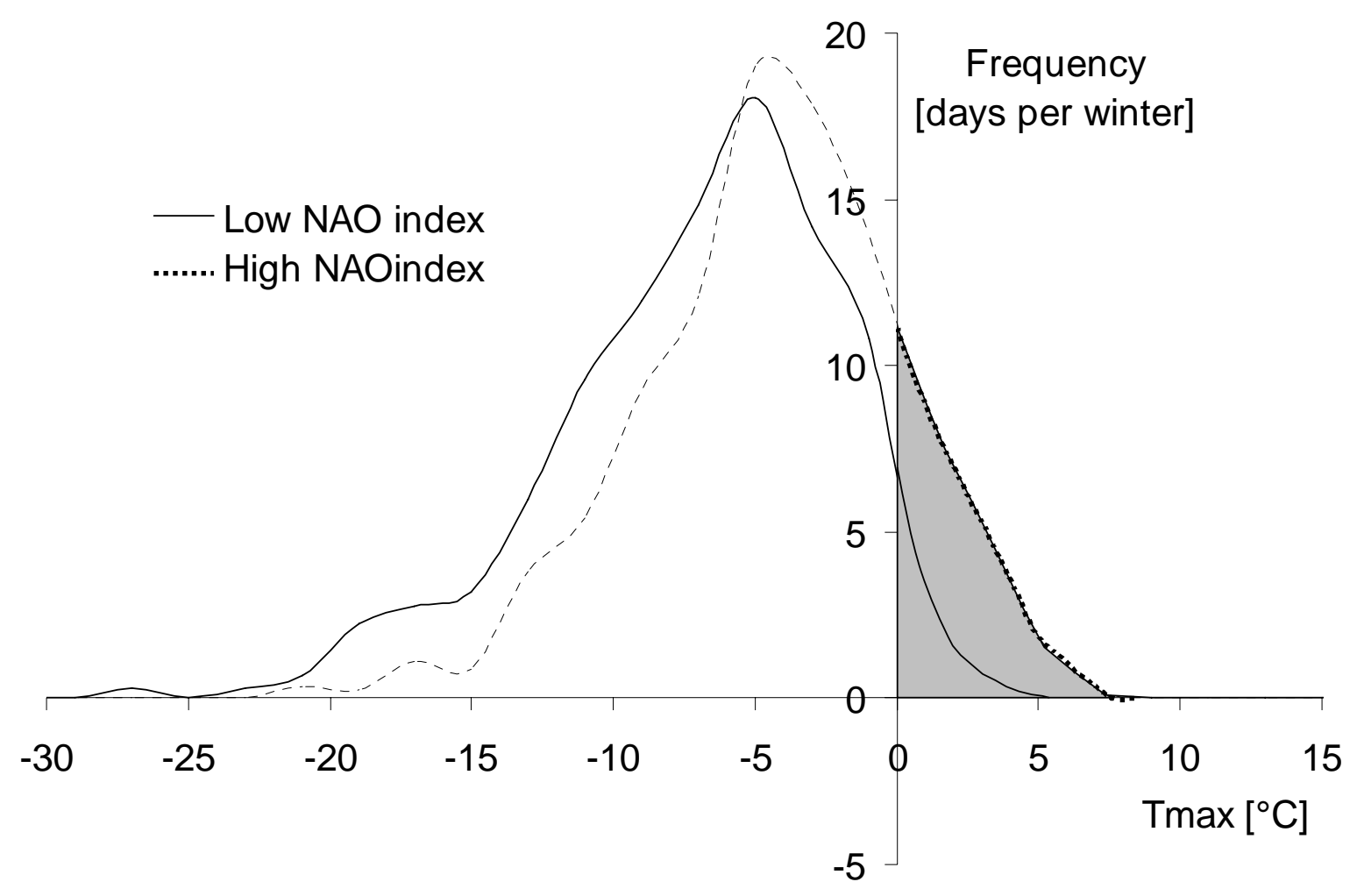

FIGURE 1 
Beniston, 2002: Climatic Change

FIGURE 2
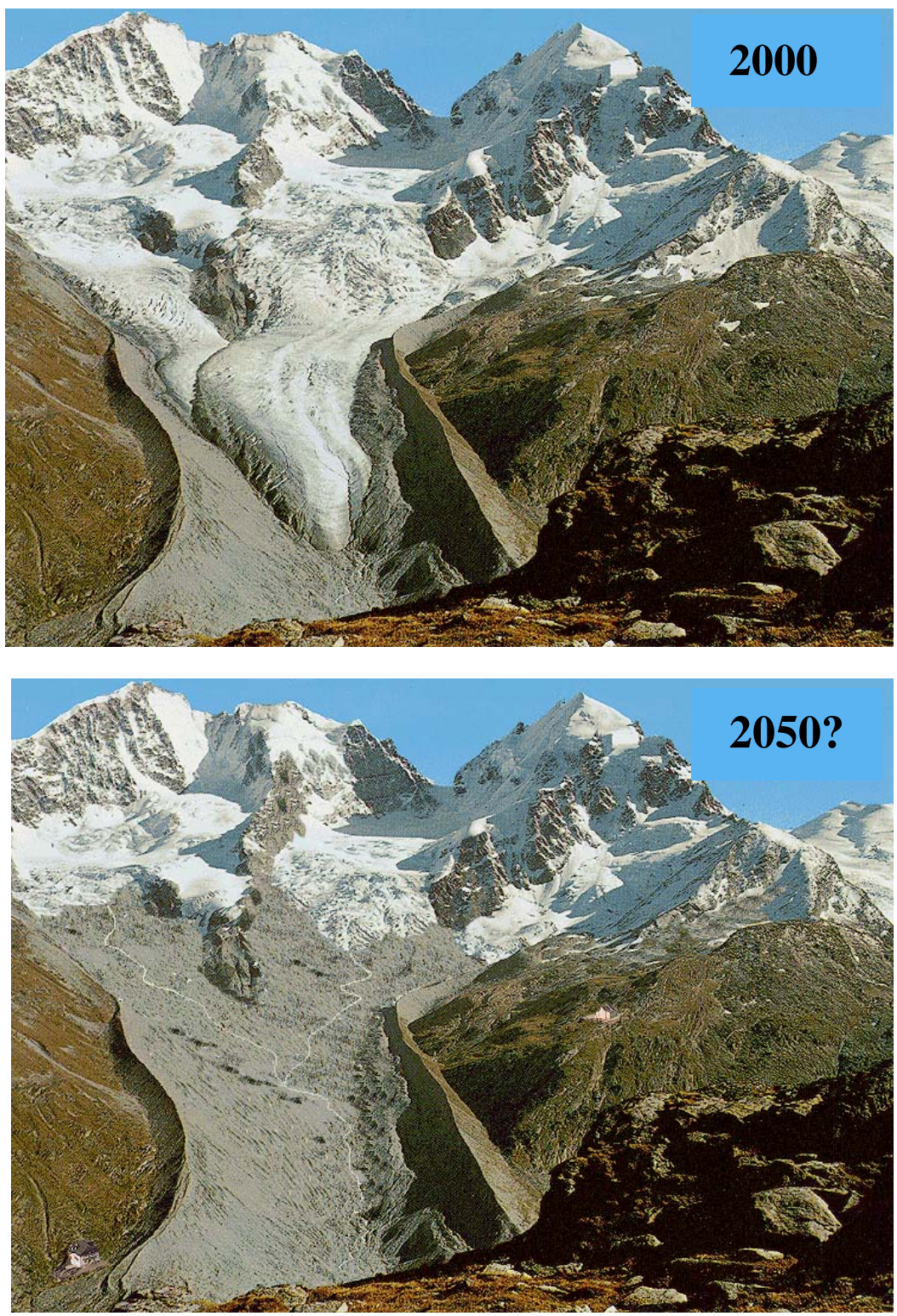
Beniston, 2002: Climatic Change

FIGURE 3

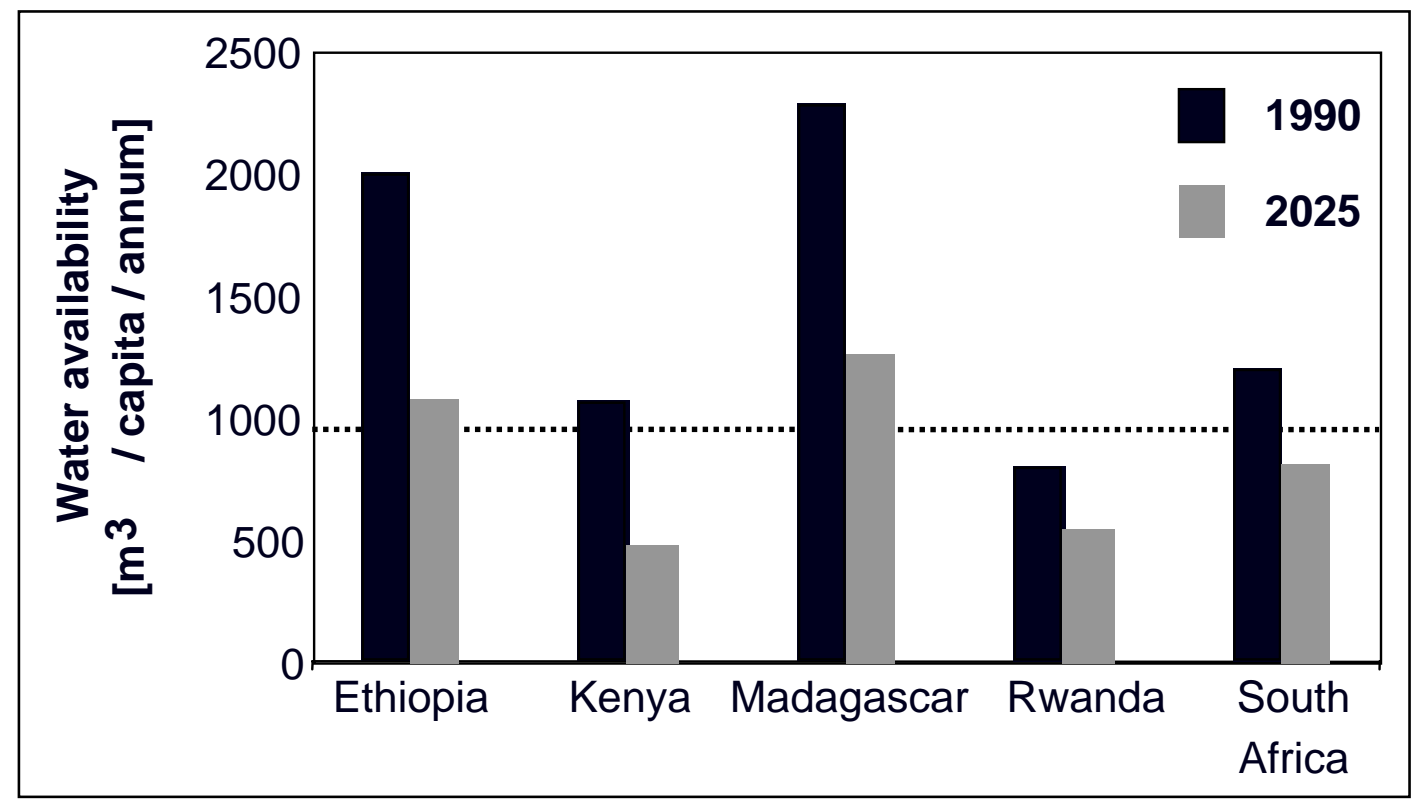


Beniston, 2002: Climatic Change

FIGURE 4

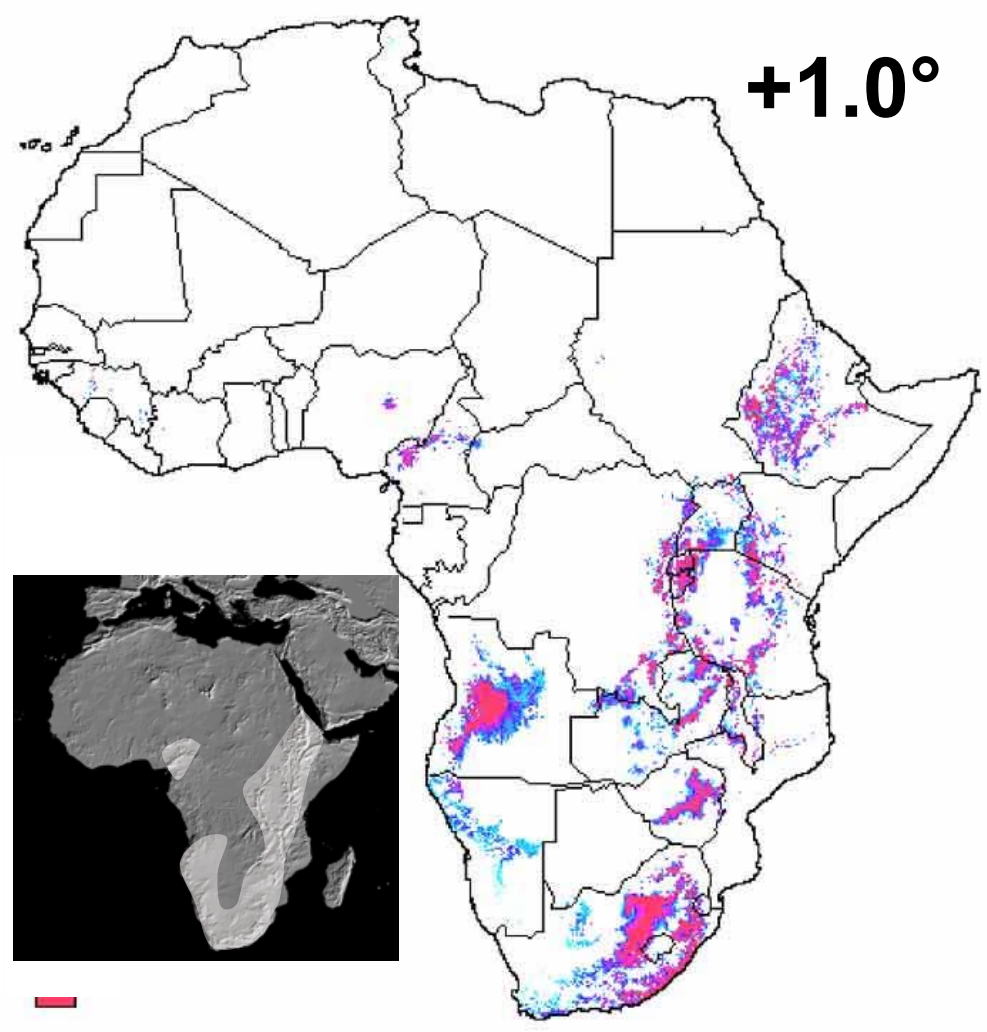


Beniston, 2002: Climatic Change

FIGURE 5

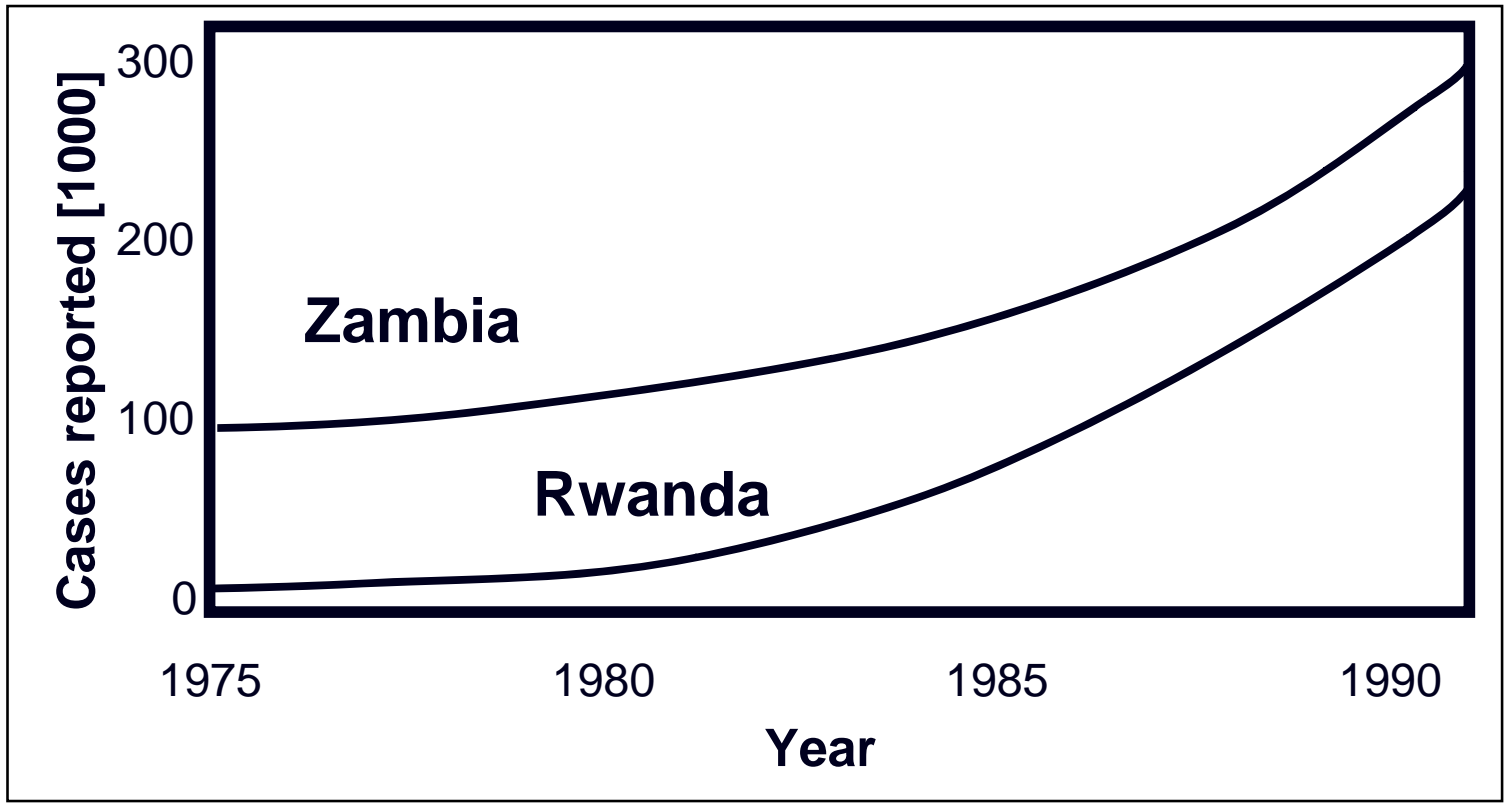

